\title{
ADDRESSING RESPONSIBILITY OF OWNERS AND MANAGERS IN CARTEL AGREEMENTS: A COMPETITION LAW PERSPECTIVE
}

\begin{abstract}
Horizontal agreements between competitors with the object/effect of reducing competition between them through market partitioning, bid rigging, production/distribution quantities limitation and price fixing are considered to be the infringements of competition law. Cartel is an agreement under which competitors agree not to compete with each other and presents the most serious form of anticompetitive behaviour. Such arrangements allow companies to exert market power they would not otherwise have by artificially restricting competition with deleterious effect on welfare. Competition authorities around the world continue to declare cartel detection and conviction in competition enforcement as their highest priority. Taking part in cartel can have severe consequences for managers as well for the undertaking. In some jurisdictions employees involved in the infringement of competition law are criminally prosecuted facing financial fines and possible imprisonment. The reason behind it is an acknowledgment by competition authorities that the mere threat of sanctions against managers and personal liability could be a more effective deterrent than the possibility of only undertaking-focused sanctions. The amount of fines imposed for antitrust infringements, and for hard core cartel violations in particular, has notably augmented over the last years. This paper will argue why managers are employed in harmful activities risking imposition of severe fines and adverse reputational impact for themselves and the owners of the undertakings they work for and what are the tools within undertaking that can reduce the risk of being involved in unlawful antitrust practices and minimize the negative impact if anticompetitive behaviour has occurred.
\end{abstract}

Key words: cartel, competition law, sanctions, managers, owners

\section{Introduction}

There has been a significant change in policy towards cartels in Europe since 1990s with growing international recognition that hard-core cartel activity consisting of market sharing, price fixing, limits on production and bid rig-

Ljiljana Pavlic, Member of the Competition Council, Croatian Competition Agency, Zagreb, Croatia, e-mail: ljiljana.pavlic@gmail.com 
ging has negative welfare economic effects and requires strict laws prohibiting it associated with efficacious penalties to deter it. Conduct that an illegal cartel orchestrates to suppress competition might be reasonably suspected of having an anticompetitive rationale. ${ }^{1}$ Within various jurisdictions, among scholars and competition enforcers there are concerns that fines imposed just on undertaking do not deter illegal conduct by individuals, managers that are actually running the companies. This has led to more support for the view that criminal sanctions should be imposed on individuals engaged in, or responsible for, the anticompetitive conduct. Almost every discovered cartel was operated by executives whose incentives may not be fully aligned with those of owners. Synchronization of individual goals with the interests of organization is the biggest challenge. ${ }^{2}$ Even though participating in cartel may benefit executives and shareholders during their period in operation, once discovered and fined, the repercussions of such behaviour can result in severe fines and reputational losses on the part of the undertaking and its management. The relationship between managers and owners is a bone of contention in recent competition law developments related to optimal liability for illegal activities and corporate crime.

\section{Restriction of competition through cartels}

Generally speaking, strategy of an undertaking is dependent on the strategies followed by its competitors. Investments in R\&D and innovations could bring positive changes in undertaking's performance on market and create new value for customers. Successful innovation and the ability of undertakings to continuously improve their innovation processes are rapidly becoming essential requirements for competitive advantage and long-term growth. However, by entering into an agreement with competitors to co-ordinate behaviour with the aim of reducing the effectiveness of competition between them, each undertaking will be able to increase price above the level that would have otherwise prevailed and consequently to increase profits. ${ }^{3}$ The objective of a cartel is to maintain the parties' respective positions on the market and to achieve pricing

$1 \quad$ Heeb Randal D., Kovacic William E., Marshall Robert C., Marx Leslie M. (2009): "Cartels as Two-Stage Mechanism: Implications for the Analysis of Dominant-Firm Conduct", Chicago Journal of International Law, Summer 2009, 10, 1, 216.

2 Cingula Marijan, Cingula Domagoj, Vuletić Ante (2012): “The Impact of Human Resource Management on Integrated Business Safety", Journal of International Scientific Publications, Economy \& Business, 6, Part 1, 2012, 196.

3 Bishop Simon, Walker Mike (2002): The Economics of EC Competition Law: Concepts, Application and Measurement ( $2^{\text {nd }}$ edition), Thomson, Sweet \& Maxwell, London, 139. 
stability or an increase in prices. ${ }^{4}$ Such activities result in higher prices, less innovation, allocative inefficiency and reduced choice for consumers.

Duration of the discovered cartels vary significantly, but one study found that cartels last on average about five years. ${ }^{5}$

Bid rigging stifles competition and occurs when competing undertakings collude on the bids to submit in tenders instead of vigorously competing with each other and is without exception considered one of the most serious infringements of competition law. Bid-rigging is a serious hard-core infringement that eliminates competition among suppliers in procurement process and increases costs for those organizing tenders. Since this occurs prevailingly in public procurement, these augmented costs are conclusively passed on to the taxpayers/consumers. Size of public procurement market varies across the states but in 2011 OECD member states spend on average 12\% of their GDP on public procurement. In Croatia, there has been an increase in the relevance of procurement market and in 2011 accounted for $9.011 \%$ of GDP, $11.99 \%$ in 2012 and $12.08 \%$ in 2013 . All those data ${ }^{6}$ show the economic significance of public procurement and coupled with other reasons led to serious penalties imposed by competition authorities especially for involvement in bid rigging.

\section{Incentives for cartel formation}

It might seem commonsensical that owners of the undertaking have bigger picture and are more interested in long-term prospect of the company they own than managers of the same undertaking. The CEO commits other people's money to build the enterprise of his vision and that way, ensures that the shareholders are rewarded for trusting their resources on the leadership of the company. ${ }^{7}$ In an economic literature on cartels, there is a prevailing view that profit-maximization is the drive for the undertakings. Owners appoint managers for a specific period of time with specific targets and goals that need to be achieved during their tenure. Managers behaviour affects the undertaking's profit and it is, to large extent, up to them to decide, how to accomplish this mission. Value based management advantages aligning interests of high level

4 Jones Alison, Sufrin Brenda (2008): EC Competition Law Text, Cases, and Materials ( ${ }^{\text {rd }}$ edition), Oxford University Press, Oxford, 859.

5 Levenstein Margaret C., Suslow Valerie Y. (2006): “What Determines Cartel Success?", Journal of Economic Literature Vol. XLIV March 2006, 85.

6 OECD (2011): Government at a glance. Size of Public Procurement Market, http://www.oecdilibrary.org/governance/government-at-a-glance- 2011_gov_glance-2011-en (14. 3. 2015).

Amponsah Emmanuel B., Onuoha Luke (2012): “Other People's Money: How CEOs Create Value For Shareholders During Good Times or Bad”, Canadian Social Science, 8, 4, 2012, 12. 
managers with those of shareholders and stakeholders. ${ }^{8}$ Values and goals should be addressed in a broader perspective even in temporal sense, making sure that undertaking is reaching full potential on longstanding basis. On more operational level, Management Information System as the techniques used by a firm to insure the proper behaviour of organizational participants should include performance indicators reflecting external environment, as well as data that are more long-term and future oriented. ${ }^{9}$

However, there is general myopia in corporate governance and ownership perspective. The rationale behind it is the fact that shareholders can relatively easy switch and move from undertaking to undertaking or invest in diversified financial products. Generally, they are interested in short-term performance of the undertaking they own since they are in majority freefloating shareholders. According to this view, employees have a greater stake in the long- run viability of the undertaking than most stakeholders. However, constant pursuit of manager's focus on more value capture instead of value creation could be strong incentive to cartel formation.

Decision to engage in collusion is typically made by senior management. ${ }^{10}$ It would be unfair to assume that all of the executive managers are involved in illegal activities, but there is general perception that older managers could be more likely engaged in cartel activity than younger ones since they have well developed wide professional networks. It is assumed that they have worked for many undertakings within same or closely linked industries that facilitate the collaboration and communication necessary to cartel formation. Consequently, cartel arrangements with competitors are much easier to achieve. In addition, if reaching retirement age, it could be presumed that involving in cartel could ensure them additional income before retirement. On the other hand, component of monetary motivation is important, but not equally for all managers and directors. ${ }^{11}$

Coherent with this view, young managers are less likely to be involved in cartel creation taking into account that in early stage of their careers they do not have extensive knowledge about market structures, activities within industry and personal connections with the most prominent people in the industry. If aware of possibility that colluding with competitors is a serious breach of competition law, they might not wish to be engaged in activities with

8 Beck Valentin (2014): "The Effects of the Implementation of Value- based Management", International Journal of Economic Sciences and Applied Research, 7, 2, September 2014, 156.

$9 \quad$ Naranjo-Gil David (2010): “Managerial Styles and Management Information Systems for Improving Organizational Performance", Journal of Positive Management, 1,1, 2010, 9.

10 Han Martijn A. (2011): Vertical Relations in Cartel Theory (doctoral disertation), Amsterdam Center for Law and Economics, 8.

11 Krasilnikova E. V. (2014): "Shareholder and Manager Features in the Context of Behavioral Characteristics, Effects and Life Cycle", European Journal of Economics and Management, $1,1,2014,285$. 
such a high risk related to individual and corporate reputation and other severe consequences once cartel will be discovered by competition authority. Managers may therefore use some other strategic options by which good reputation is maintained and competitors outperformed. In addition since in some states director disqualification and imprisonment is applied for those caught in antitrust cartel activity, the younger managers at the beginning of their career could be more precautious and more interested in protecting their long-term careers from reputational damage.

Taking into account impact of fixed versus variable salary components, $\mathrm{Han}^{12}$ found that fixed components can facilitate collusion with a short-term contract, while not affecting cartel stability with a long-term contract. With that in mind, it is easier to understand how short-term perspective from owners and managers can facilitate cartel formation and can produce perverse impact on business and society.

\section{Attribution of blame through sanctions - owners and managers}

One has to distinguish between corporate, also called administrative and individual, criminal sanctions. Although both are regarded as punitive sanctions, these two types of sanctions have specific features, with corporate sanctions generally being seen as less rigorous than criminal sanctions. In some jurisdictions like United States of America culpable individuals, can be subject to imprisonment and financial fines. Individual sanctions are introduced to specifically fine managers responsible for the cartel formation considering that corporate fines mainly affect shareholders. As Wheelan ${ }^{13}$ notes in his article such criminalization must respect the human rights of the accused.

\subsection{Corporate sanctions}

Corporate fines are imposed by competition authorities in prevailing number of member states of European Union on cartel members in amount that cannot exceed $10 \%$ of annual turnover of undertaking in question. The amount of total fines imposed by the national competition authorities and European Commission are inclining every year and the risk of negative occurrence and high financial penalties for undertakings involved in anticompetitive practices is immense. For example, the total amount of fines imposed by the European Commission in the period 2010-2014 was 8,7 billion $€$. The size of these

Han A. Martijn, 48.

13 Whelan Peter (2012): "Legal Certainty and Cartel Criminalisation within the EU Member States", The Cambridge Law Journal, 71, 3, Nov 2012, 677-702. 
corporate fines depends on various factors such as severity of infringement, duration of the cartel, potential mitigating and aggravating circumstances.

Fining policy covers a wide spectrum of different factual circumstances and it is very difficult, almost impossible, apart from the top ceiling of the fine, for undertaking to envisage in advance what the final outcome of the fine will be. One thing they can be sure of, it is that the fine will most probably be high in order not just to punish undertaking in question for cartel participation but to have deterrent effect for the others not to engage in the future in anticompetitive practices.

As in Europe, in United States of America, in Asia and basically worldwide corporate sanctions represent main competition enforcement and deterrent tool for cartel involvement.

Figure 1: Fines in $€$ (European Commission, Directorate General for Competition)

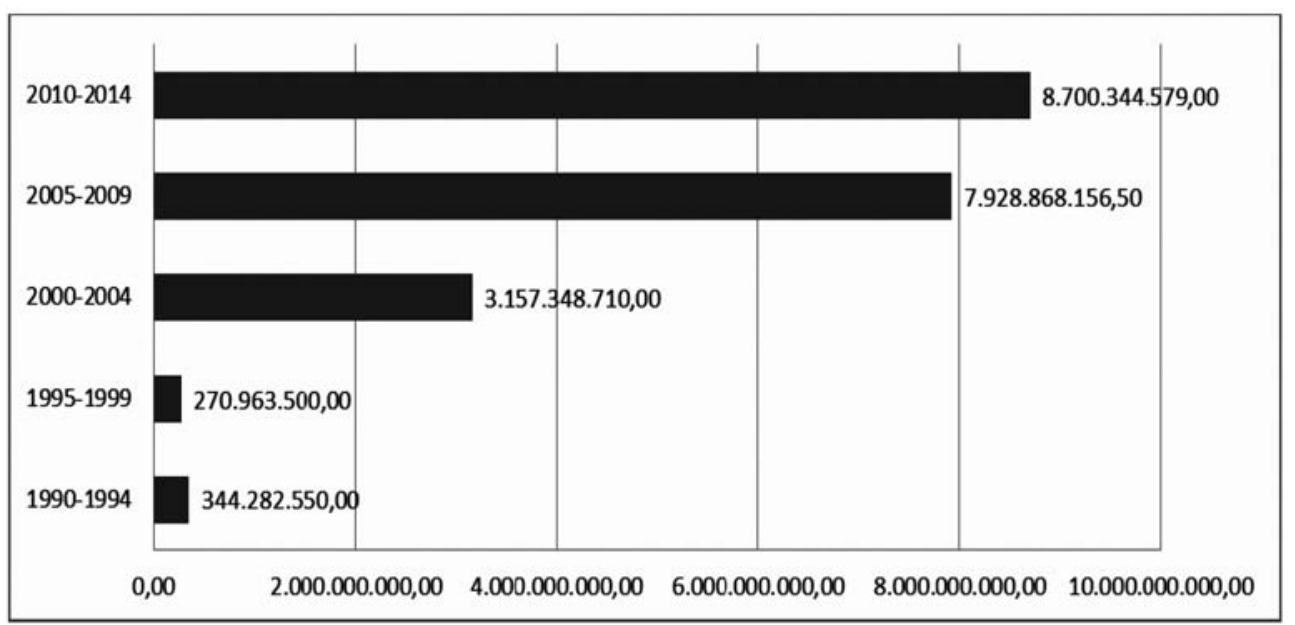

Source: European Commission, Directorate General for Competition

Another way of sanctioning is the "naming and shaming" of enterprises. ${ }^{14}$ Press releases by competition authorities and publicly available decisions establishing hard-core infringements of competition law may have a disincentive effect. European Commission, Department of Justice and majority of the regulators in countries that have enacted competition law use this practice not just for "naming and shaming" purpose but for the transparency issue as well. On top of corporate fine and bad reputation, victims of cartels can sue the cartel in court and claim private damages for the economic harm suffered. While the USA has decades of experience with private damages law suits, in European Union Directive on antitrust damages actions was adopted in 2014.

14 Cseres Katalin J., Schinkel Maarten Pieter, Vogelaar Floris O. W. (2006): Criminalization of Competition Law Enforecement: Economic and Legal Implications for the EU Member States, Edward Elgar Publishing, Cheltenham/Northampton, 178. 


\subsection{Individual sanctions}

Some jurisdiction incorporate individual sanctions aimed at managers personally involved in cartelization practices. Most notably, in the United States of America, involved employees are criminally prosecuted and face substantial personal fines and even incarceration. In Europe, situation differs since European competition law is not targeting liable individuals, so cartels discovered by European Commission only could be punished by corporate fines. On the other hand, some EU member states have enacted laws to prosecute also employees involved in cartel. Legal solutions also vary across member states, in some like in Ireland and the United Kingdom individuals can be criminally prosecuted, in the Netherlands, like in Poland individuals can be personally fined, in Croatia individuals cannot be personally fined, but can face imprisonment sentence for bid-rigging practices. In Germany, in which bid-rigging can be sanctioned with up to 5 years in prison, financial fines for participation in bid-rigging cannot exceed 1 million $€$. Poland recently introduced amendments to competition act that enable the competition authority to levy a fine of up to $500.000,00 €$ against company manager responsible for anti-competitive agreement.

Bid rigging is one of the most widely prosecuted forms of collusion and additional fines through criminal offence sanctions for this specific type of collusion is often available. The United Kingdom took step further introducing the system that allows for "director disqualification". Disqualification order can be issued against manager if they know, or ought to have known that the undertaking had breached competition law. Any undertaking directors involved in the cartel may be disqualified from acting as a director for up to 15 years. In 2008, Bryan Allison, David Brammar and Peter Whittle were disqualified from acting as company directors for periods from between five and seven years for their role in the marine hose cartel agreement.

When it comes to the situation, who can be blamed or fined for law infringement on individual level, it is necessary to highlight that although not all employees, consisting of executives and non-executives cannot have profound knowledge of competition act provisions, it is necessary to build awareness within an undertaking that especially bid-rigging and other forms of collusion with competitors might come under scrutiny of competition regulators with severe consequences for the owners of the undertaking and managers involved in unlawful activities. Some employees cannot be held responsible and eventually fined, but managers in charge of respectable unit can be sanctioned for breaching their duty of supervision.

In the United States of America, there has been growth in percentage of individuals sentenced to prison, with peak of $70 \%$ of prosecuted individuals send to prison in period 2010-2013. The same goes for the length of prison sentence. Average prison sentence accounts for 25 months for the same period, longer 
period of time comparing to 2000-2009 and more than three times the average of eight months in 1990-1999. Of course, duration of imprisonment can vary and the longest ever prison sentence Department of justice obtained for antitrust violation and accounted for 5 years and it was related to coastal shipping investigation.

Figure 2: USA - Percentage of individuals sentenced to prison

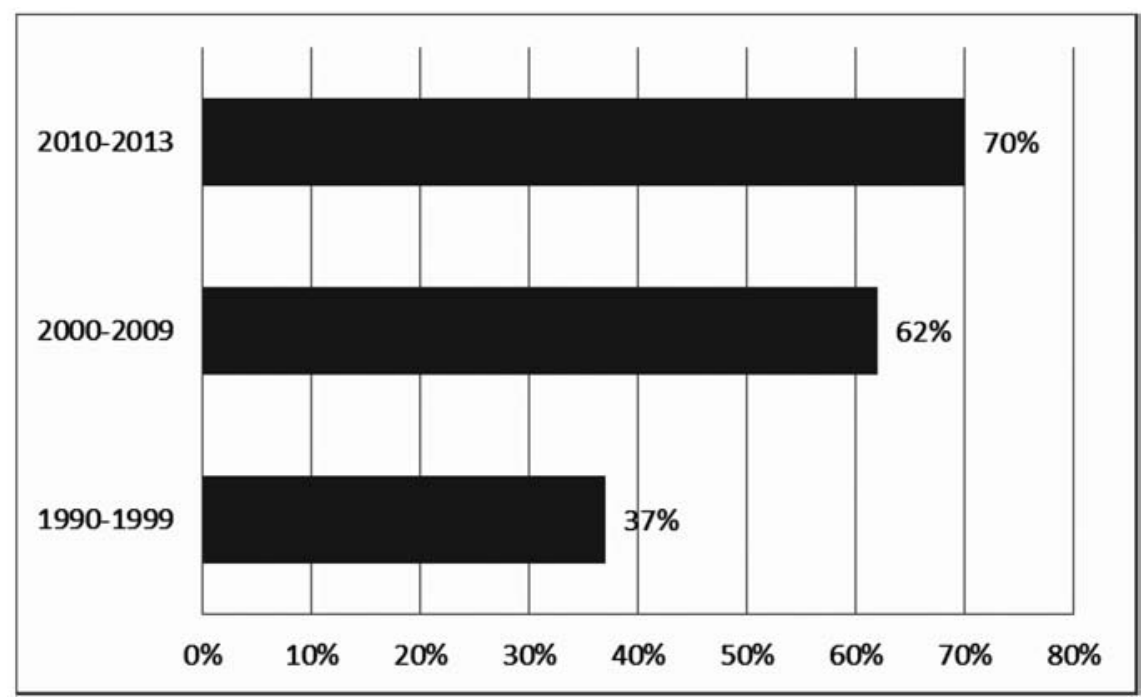

Source: USA, Department of Justice

Figure 3: USA - Average prison sentence for cartel involvement in months

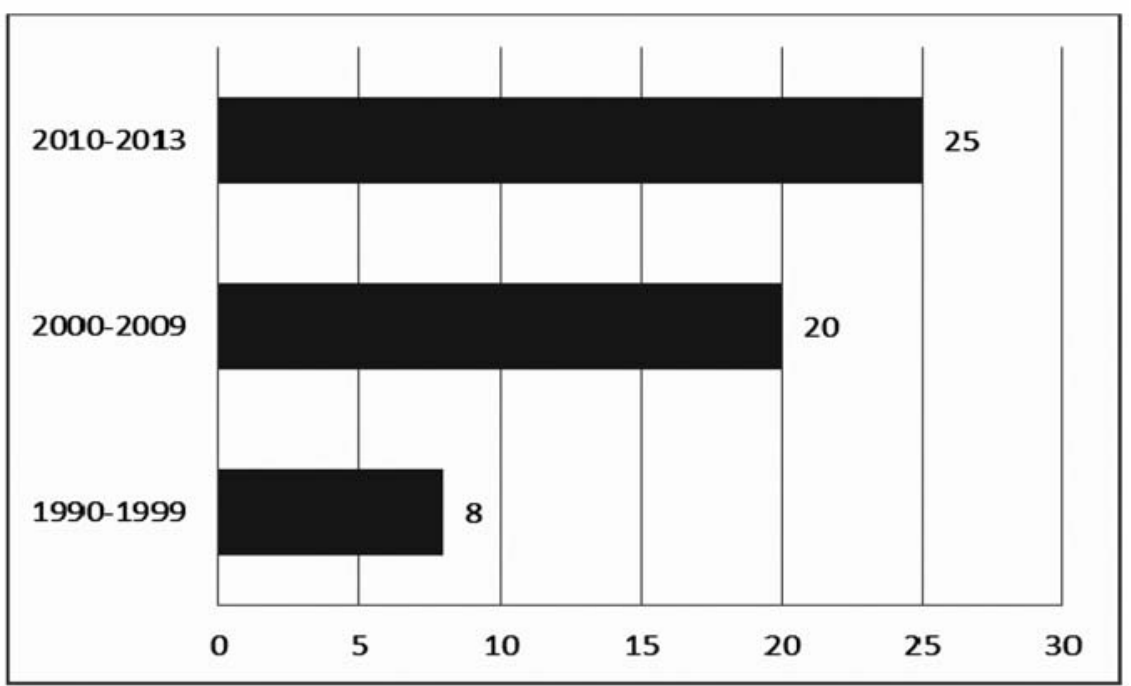

Source: USA, Department of Justice 
In auto parts cartel, well-known cartel with various jurisdiction opening formal proceedings against cartel participants, when one of the cartel members - Diamond Electric pleaded guilty in 2014 for conspiring to fix prices of ignition coils, two high ranked employees, president and vice president also plead guilty and agreed to serve 16 months and 13 month jail sentences respectively.

\subsubsection{International aspect of individual sanctions}

The possible manoeuvring room afforded by difference in legal frameworks and limitation of national laws could allow culpable individuals to escape prison sentence and fines. But, 2013 was the turning point for extradition issues related to breach of antitrust law. For the first time, the United States of America succeeded in extraditing foreign national indicted for antitrust violations. During the summer of 2013, Romano Pisciotti, former manager of Parker IT who holds Italian citizenship, was arrested at the airport in Germany. He was arrested at USA DOJ's request for price-fixing charges. The applicable bilateral agreement between Germany and the United States of America require so called dual criminality meaning that the conduct in question must constitute a criminal offense in both jurisdictions. Pisciotti's alleged cartel conduct included bid-rigging, which made his extradition to the United States of America possible. Moreover, the Higher Regional Court of Frankfurt ruled that non-German citizens can be extradited from Germany to the USA. Before the court in the USA he pleaded guilty of price-fixing charges and was fined with 50.000,00 \$ and 24 months in prison. Piscotti was arrested in 2013 and at that time he was not working for Parker ITR. He left that undertaking in 2006, after more than 20 years within this company. DOJ discovered that Parker ITR had participated in a global cartel related to marine hoses. Cartel members agreed to divide the market, allocate shares of marine hose market and basically not to compete with each other. They share all necessary information through one of them, who served as a coordinator of their activities and information send.

The risks of participating in a bid rigging cartel are apparent: high fines and reputational damage through bad publicity for the company, imprisonment for managers; substantial damages owed to customers; and possible exposure to further criminal investigations. Contraventions of competition law and related consequences can be prevented if undertakings enforce effective compliance programs.

\section{Compliance programs}

Compliance programs are introduced in order to assure that undertaking is following the rules imposed by the government concerning wide range of legal regulation, including competition law. These programs are composed of inter- 
nal procedures and instructions aim at educating employees about competition law policy and unlawful actions considered under competition act.

Some of competition authorities ensure web accessibility of main instruction and guidelines for compliance programs aiming at the first place at small and medium size undertakings that often do not have in-house lawyer or specialist in competition policy. Since size of the undertaking for the application of rules related to such hard-core restriction like price-fixing, bid rigging is irrelevant, it is crucial that all participants in the market are aware of "don'ts" in the competition culture. The role of competition authorities is important in building awareness of usefulness of antitrust compliance program implementation seeing that the ultimate goal is to prevent the formation of cartels. Guidance for compliance competition programs is available on websites of many institutions including European Commission, French competition agency, Croatian competition agency.

To be successful compliance competition programs should be clear and easy understandable to vast majority of employees and written in a way that all necessary information about specific anticompetitive behaviour presenting antitrust risks like price fixing, market sharing and bid- rigging are included.

Compliance programs include also related monitoring and auditing through internal inspections and investigations of documents, building corporate compliance training courses. When well-designed and adequately implemented and regularly updated, compliance programs have the potential to deter and detect illicit managerial activities and in overall to minimize the risk of involvement in anticompetitive conduct.

Many undertakings realized that it is better to accept this and build the safety valves into the system than to ignore it and risk total collapse on individual and corporate level once discovered as cartel member by competition authority.

Although compliance programs are associated with positive impact on employees and shareholders, there could be some negative aspects as well. Negative effect can arise when employees inclined to engage in antitrust infringements learn from compliance training how to engage more effectively in antitrust infringements or how to avoid detection and punishment. ${ }^{15}$ Whereas compliance programs are not perfect they bring positive change in corporate culture.

Wils P. J. Wouter (2013): “Antitrust Compliance Programmes \& Optimal Antitrust Enforcement", Journal of Antitrust Enforcement, Vol. 1, No. 1, April 2013, 53. 


\section{Leniency programs}

Leniency program is often seen as the most powerful instrument competition authorities have to detect cartels. Through leniency schemes authorities offer immunity from fines or a reduction of fines for undertakings that provide sufficient information about a cartel in which they participated, allowing competition authorities to launch an inspections.

In jurisdiction where individuals can be prosecuted for cartel involvement, like the United States of America, undertaking and responsible individuals could avoid fines, criminal conviction and incarceration if they meet the requirements of the leniency program set by competition authority in charge. Individual leniency policy for individuals in the USA grants the involved employee full immunity when coming forward with incriminating evidence. In the UK, if undertaking applies for leniency, in addition, protection from director disqualification proceedings for all of its cooperating directors is granted.

The objective of such leniency programs is to detect and uncover unlawful anticompetitive behaviour and to encourage undertakings and individuals to blow the whistle. Blowing the whistle is the second best choice only since the best is that cartel did not ever exist.

\section{Conclusion}

Cartel enforcement has never been more strenuous, and the stakes have never been higher for undertakings and managers under investigation for allegations of competition law infringements. This paper explains the reasoning behind the collusion and argues that short term perception of owners and managers facilitate cartel arrangements.

Sometimes undertakings participate in collusion to get an extra profit and reduce costs. It may seem like the paradox that reaping extra gains may require an increase rather than a decrease in costs, but the paradox is more apparent than real since unfortunately many cartels still remain undiscovered.

In order to fight cartels, competition authorities apply a diverse array of tools and sanctions to deter, detect and eventually punish undertakings and individuals for infringements of competition law. According to the data presented in this paper average penalties imposed by competition authorities continue to increase. The average fines over years are significantly higher and overall fining policy has become tougher. Additionally, cartel damage claims against cartel members from companies and individuals who claim to have suffered damages as a result of specific cartel are on the rise. Being a cartel member brings a risk of jail sentence for responsible managers and hefty fines for undertaking if caught. The risks concomitant with this cartel practice cannot 
be ignored. A shock of this magnitude would cause havoc in the strongest of undertakings, so it came as no surprise that there is growing trend of employing compliance programs within undertakings to minimize the risk of wrongdoing. If aware of cartel participation, undertakings and in some jurisdictions individuals can apply for leniency and immunity from fines, partial or full, is available for those who voluntarily come forward and report and document the cartel activity to law enforcers.

\section{Literature}

- Amponsah Emmanuel B., Onuoha Luke (2012): "Other People`s Money: How CEOs Create Value For Shareholders During Good Times or Bad", Canadian Social Science, 8, 4, 2012, 8-14

- Beck Valentin (2014): “The Effects of the Implementation of Value-based Management", International Journal of Economic Sciences and Applied Research, 7, 2, September 2014, 153-165

- Bishop Simon, Walker Mike (2002): The Economics of EC Competition Law: Concepts, Application and Measurement (2nd edition), Thomson, Sweet \& Maxwell, London

- Cingula Domagoj, Cingula Marijan, Vuletić Ante (2012): “The Impact of Human Resource Management on Integrated Business Safety", Journal of International Scientific Publications, Economy \& Business, 6, Part 1, 2012, 93-2011

- Cseres Katalin J., Schinkel Maarten Pieter, Vogelaar Floris O. W. (2006): Criminalization of Competition Law Enforcement: Economic and Legal Implications for the EU Member States, Edward Elgar Publishing, Cheltenham/Northampton

- Department of Justice - Criminal Enforcement (2015): http://www.justice. gov/atr/public/criminal/264101.html (12. 3. 2015)

- European Commission - Competition - Cartel Statistics (2015): http:// ec.europa.eu/competition/cartels/statistics/statistics.pdf (7. 4. 2015)

- Han Martijn A. (2011): Vertical Relations in Cartel Theory (doctoral disertation), Center for Law and Economics, Amsterdam

- Heeb Randal D., Kovacic William E., Marshall Robert C., Marx Leslie M. (2009): "Cartels as Two-Stage Mechanism: Implications for the Analysis of Dominant-Firm Conduct", Chicago Journal of International Law, Summer 2009, 10, 1, 213-231

- Krasilnikova E. V. (2014): "Shareholder and Manager Features in the Context of Behavioral Characteristics, Effects and Life Cycle", European Journal of Economics and Management, 1, 1, 2014, 270-291 
- Jones Alison, Sufrin Brenda (2008): EC Competition Law Text, Cases, and Materials ( $3^{\text {rd }}$ edition), Oxford University Press, Oxford

- Levenstein Margaret C., Suslow Valerie Y. (2006): "What Determines Cartel Success?", Journal of Economic Literature, XLIV, March 2006, 43-95

- Naranjo-Gil David (2010): "Managerial Styles and Management Information Systems for Improving Organizational performance", Journal of Positive Management, 1, 1, 2010, 3-10

- OECD (2010): Government at a glance. Size of Public Procurement Market, http://www.oecd-ilibrary.org/governance/government-at-a-glance- 2011_gov_ glance-2011-en (14.3.2015)

- Whelan Peter (2012): "Legal Certainty and Cartel Criminalisation within the EU Member States”, The Cambridge Law Journal, 71. 3, Nov 2012, 677-702

- Wils Wouter P. J. (2013): "Antitrust Compliance Programmes \& Optimal Antitrust Enforcement", Journal of Antitrust Enforcement, 1, 1, April 2013, 52-81 
Ljiljana Pavlic, članica Vijeća za zaštitu tržišnog natjecanja

Agencija za zaštitu tržišnog natjecanja

Zagreb, Hrvatska

\section{ODGOVORNOST VLASNIKA I MENADŽERA U KARTELNIM SPORAZUMIMA IZ UGLA ZAKONSKE REGULATIVE O ZAŠTITI KONKURENCIJE}

\section{S a ž e t a k}

Horizontalni sporazumi između konkurenata sa ciljem/posledicom smanjenja konkurencije među njima kroz podelu tržišta, nameštanje ponuda kroz proces javne nabavke, limitiranje količina proizvodnje/distribucije i fiksiranje cena, smatraju se povredama prava konkurencije. Kartel je sporazum po kojem su konkurenti saglasni da ne konkurišu jedni drugima i predstavlja najteži oblik antikompetitivnog ponašanja. Takvi sporazumi omogućavaju preduzetnicima da ispoljavaju tržišnu snagu koju inače ne bi imali, na način da ograničavaju tržišno takmičenje s negativnim učinkom na blagostanje. Nadležni za zaštitu tržišnog takmičenja širom sveta otkrivanje kartela i kažnjavanje za učestvovanje u njima deklarišu kao najvažniji prioritet svog delovanja. Učestvovanje u kartelu može imati ozbiljne posledice kako za menadžere tako i za kompaniju. U nekim jurisdikcijama zaposleni uključeni u povredu prava konkurencije su krivično gonjeni, pa se suočavaju sa finansijskim kaznama i mogućim kaznama zatvora. Razlog toga leži u shvatanju nadležnih za zaštitu tržišnog takmičenja, kako sama mogućnost kažnjavanja menadžera i lična odgovornost mogu imati veći odvraćajući učinak od mogućnosti kažnjavanja same kompanije. Iznosi izrečenih kazni za povrede pravila o zaštiti konkurencije, a posebno za najteže oblike kartela, značajno su povećani proteklih godina. Ovaj rad pokazuje zašto se menadžeri upuštaju u štetne aktivnosti rizikujući visoke kazne i svoju reputaciju kao i reputaciju vlasnika kompanija za koje rade; koja su sredstva raspoloživa unutar kompanija čijom primenom može da se smanji rizik involviranja u nezakonitu praksu monopolskog ponašanja, kao i kako minimizirati negativan učinak ukoliko se antikompetitivno ponašanje ipak dogodi.

Ključne reči: kartel, pravo konkurencije, sankcije, menadžeri, vlasnici 